\title{
TENDENCIES IN POLITICAL BEHAVIOR OF MEN AND WOMEN - A STUDY ON THE BEHAVIOR OF VIETNAMESE POLITICAL ELITES TOWARD THEIR PROMOTION OPPORTUNITIES
}

\author{
TENDENCIAS EN EL COMPORTAMIENTO POLÍTICO DE HOMBRES Y \\ MUJERES: UN ESTUDIO SOBRE EL COMPORTAMIENTO DE LAS ELITES \\ POLÍTICAS VIETNAMÉS HACIA SUS OPORTUNIDADES DE PROMOCIÓN
}

\author{
Huong Thi Tran ${ }^{1} *$; Thuc Thi Le ${ }^{2}$. \\ ${ }^{1}$ Academy of Journalism and Communication (AJC), Hanoi, Vietnam. tranhuongxdd@gmail.com \\ ${ }^{2}$ Academy of Politics Region I, Hanoi, Vietnam. lethithucsky@gmail.com \\ *Corresponding author: Huong Thi Tran. e-mail: tranhuongxdd@gmail.com
}

Purpose of the study: This paper aims to explore some of the crucial reasons limiting the contemporary participation of Vietnamese women in political leadership by reviewing the attitudes of male and female political elites toward opportunities for political promotion Methodology: The population of this research is the leaders and potential leaders of the Vietnamese political system. The purposive sampling method was used, resulting in 324 respondents. In addition, in-depth interviews were conducted with 21 government officials. Quantitative data resulting from questionnaires were processed using the Statistical Package for the Social Sciences (SPSS) software for Windows, version 19. Qualitative data were processed manually. No discussion or explanation.

Main Findings: The study results show that the majority of Vietnamese political elites are willing to take up opportunities for promotion. However, women's readiness to accept opportunities for promotion is often lower than that of men, due to social expectations on their traditional gender roles. Besides, improper legal frameworks and policies significantly contribute to women having less political ambition and giving up on their dreams earlier than their male counterparts.

Applications of this study: The results of this study are useful for the Vietnamese Government to develop measures for removing the obstacles that hinder women's political participation.

Novelty/Originality of this study: This study uses data from the author's original survey.

Keywords: political behavior; promotion opportunities; ellites; gender role; retirement age.

Cómo citar:

Thi Tran, Huong \& Thi Le, Thuc. (2021). Tendencies in political behavior of men and women - a study on the behavior of Vietnamese political elites toward their promotion opportunities. Revista de Investigaciones Universidad del Quindio, 33(2), 6-19. https:// doi.org/10.33975/riuq.vol33n2.512

Información del artículo: Recibido: 12 mayo 2021; Aceptado: 18 julio 2021

Revista de Investigaciones Universidad del Quindío, 33(2), 6-19; 2021.

ISSN: 1794-631X e-ISSN: 2500-5782

Esta obra está bajo una licencia Creative Commons AtribuciónNoComercial-SinDerivadas 4.0 Internacional. 
Propósito del estudio: Este artículo tiene como objetivo explorar algunas de las razones cruciales que limitan la participación contemporánea de las mujeres vietnamitas en el liderazgo político mediante la revisión de las actitudes de las élites políticas masculinas y femeninas hacia las oportunidades de promoción política.

Metodología: La población de esta investigación son los líderes y líderes potenciales del sistema político vietnamita. Se utilizó el método de muestreo intencional, lo que resultó en 324 encuestados. Además, se realizaron entrevistas en profundidad con 21 funcionarios gubernamentales. Los datos cuantitativos resultantes de los cuestionarios se procesaron utilizando el software Statistical Package for the Social Sciences (SPSS) para Windows, versión 19. Los datos cualitativos se procesaron manualmente. Sin discusión ni explicación.

Principales hallazgos: Los resultados del estudio muestran que la mayoría de las élites políticas vietnamitas están dispuestas a aprovechar las oportunidades de promoción. Sin embargo, la disposición de las mujeres a aceptar oportunidades de ascenso suele ser menor que la de los hombres, debido a las expectativas sociales sobre sus roles tradicionales de género. Además, los marcos legales y políticas inadecuados contribuyen significativamente a que las mujeres tengan menos ambición política y renuncien a sus sueños antes que sus contrapartes masculinas.

Aplicaciones de este estudio: Los resultados de este estudio son útiles para que el gobierno vietnamita desarrolle medidas para eliminar los obstáculos que obstaculizan la participación política de las mujeres.

Novedad / originalidad de este estudio: este estudio utiliza datos de la encuesta original del autor.

Palabras clave: comportamiento político; oportunidades de promoción; élites; rol de género; edad de jubilación.

\section{INTRODUCTION}

Over the last several decades, there have been considerable improvements in gender equality in most societies. Advancements in education for females, women's life expectancy, health care and reproductive services, and a narrowing gender gap in employment, have been occurring worldwide, especially in developing countries. However, despite such progress, 'gender discrimination remains pervasive in many dimensions of life - worldwide' (World Bank, 2001, p.1). Specifically, according to many authors, politics is one of the most hostile places for women in almost all societies (EtzioniHalevy, 2004; Fleschenberg, 2003; InterParliamentary Union, 2000; Kenworthy and Malami, 1999; Nelson and Chowdhury, 1994; Norris and Inglehart, 2001; United Nations, 2000).

The monopolization by men at the elite levels of corporate power is observed almost everywhere
(Inter-Parliamentary Union, 2008; Kent and Moss, 1994; Norris and Inglehart, 2001; United Nations, 2000). Many activities have been carried out around the world to promote women's participation in political leadership. Notably, Nordic countries have attained achievements that are admired by the rest of the world. Vietnam has consistently affirmed and tried to achieve gender equality in all areas of social life, including the political arena. Many documents, directives, resolutions, and policies of the Communist Party and the State of Vietnam demonstrate this spirit.

However, it is a fact that in many places women are not always able to adequately contribute to the functioning of the political system. In Vietnam, gender inequality continues to prevail in many aspects of life, especially in politics. Currently, only $27.1 \%$ of National Assembly deputies are female, and there are no female ministers in the government's 20 ministries. There are many complex and intertwined causes that lead to such a situation, including structural, 
institutional, and cultural causes.[done] This article explores some of the important reasons limiting the contemporary participation of Vietnamese women in political leadership by reviewing the attitudes of male and female political elites towards opportunities for political promotion. The research findings show that there are different tendencies in the political behaviors of Vietnamese men and women, with most differences attributable to both traditional cultural norms and government policy.

\section{METHODOLOGY}

Based on the findings of a study on gender power and political leadership in Vietnam recently conducted by the authors, this article attempts to answer the following questions: (1) how differently do Vietnamese men and women react towards opportunities for their own political advancement? And (2) why do they have these different attitudes. In other words, by using primary data we make an effort to describe different reactions of Vietnamese political elites towards opportunities for promotion. More importantly, the paper proves that not only do traditional cultural norms hinder the participation of Vietnamese women in contemporary political leadership, as commonly believed, but that current policies also play a significant role.

Besides document analysis, the study uses both quantitative and qualitative methods to collect and analyse relevant data. A survey was conducted to collect quantitative data. Selfcompleted questionnaires were administered to 400 trainees of the Ho Chi Minh National Academy of Politics, and to leaders and potential leaders of the political system, with the expectation that around 300 questionnaires would be returned. The response rate was high, at $81 \%$, since 324 respondents returned their questionnaires (133 females and 191 males). For qualitative data, ten female and eleven male government officials were interviewed to obtain in-depth insights into the cases of persons who are directly involved in the process of selecting political cadres. They are positioned officials working at the central, provincial, district, and local levels of government administration. The informants were trained and are still in training in the Ho Chi Minh National Academy of Politics. Quantitative data resulting from the questionnaires were processed using Statistical Package for the Social Sciences (SPSS) software for Windows, version 19. Comparative analysis was employed to show the differences between various aspects of the male and female political elites. The major methods of quantitative analysis include descriptive statistics of frequency and percentage distribution, cross tabulation, and tests of relationships between variables. Pearson Chi-Square significance tests were used where applicable.

\section{RESEARCH FINDINGS}

When answering the question "Imagine you got an offer to move to a higher level position in your political career, how would you accept it?", male and female respondents chose different options. Overall, more than $72 \%$ would happily accept the offer. Over one-fifth of respondents, meanwhile, have no special feeling, even though they would still opt to accept such an offer. The proportions of those accepting the offer with reluctance are less than 5\% for females and nearly $3 \%$ for males. This means that whether or not the offer of political promotion meets the respondent's desire, he or she is almost certain to accept it.

The patterns of answers by male and female respondents, however, differ slightly. The option "accept happily" accounts for a larger share of male respondents than that of female respondents. In contrast, female respondents are more likely than their male counterparts to reluctantly accept the offer, or refuse the offer. Nevertheless, such likelihood among female respondents remains rather small in absolute terms (just over 10\%). 
Table 1: Overall attitudes toward further promotion, by gender

Unit: Percentage

\begin{tabular}{l|r|r|r}
\hline & \multicolumn{1}{|c|}{ Male } & \multicolumn{1}{c|}{ Female } & \multicolumn{1}{c}{ Total } \\
\hline Accept happily & 74.6 & 69.8 & 72.6 \\
\hline $\begin{array}{l}\text { Accept with no } \\
\text { special feeling }\end{array}$ & 22.2 & 19.8 & 21.3 \\
\hline $\begin{array}{l}\text { Accept } \\
\text { reluctantly }\end{array}$ & 2.6 & 4.0 & 3.2 \\
\hline Refuse & 0.5 & 6.4 & 2.9 \\
\hline Total & $\begin{array}{r}100.0 \\
(N=189)\end{array}$ & $\begin{array}{r}100.0 \\
(N=126)\end{array}$ & $\begin{array}{r}100.0 \\
(N=315)\end{array}$ \\
\hline
\end{tabular}

Source: Author's survey

The answers, meanwhile, appear to be more complicated across age groups of men and women. The proportion of respondents who would happily accept an offer of political promotion tends to decrease along with the age of respondents. Specifically, such a proportion is highest, at nearly $78 \%$, in the age group 34 and younger, whilst lowest, just under $66 \%$, among those 45 or over. Meanwhile, the proportions of those accepting the offer with no feeling among the age groups 35-44 and 45 and over are roughly the same, around $24 \%$, and are significantly higher than among the first age group (reaching nearly $17 \%$ ). The share of respondents accepting the offer with hesitation is highest among those 45 or older, but is modest at over $2 \%$ for both younger age groups. Finally, only less than $1 \%$ of respondents between 35-44 would refuse the offer, compared to the corresponding figures of over 3\% and over $4 \%$ for the age groups younger than 35 and older than 44. It could be argued, then, that younger respondents are more likely to happily accept the offer, while older ones may have been waiting too long to be joyful about the offer and for opportunities for political promotion.

Table 2: Attitudes towards further promotion, by gender and age

\begin{tabular}{l|l|r|r|r}
\multicolumn{1}{c}{} & \multicolumn{1}{c}{ Unit: Percentage } \\
\hline \multicolumn{1}{c|}{ Age group } & \multicolumn{1}{c}{ Attitudes } & \multicolumn{1}{c}{ Male } & \multicolumn{1}{c}{ Female } & \multicolumn{1}{c}{ Total } \\
\hline$<35$ & Accept happily & 77.2 & 78.9 & 77.9 \\
\hline & Accept with no special feeling & 21.1 & 10.5 & 16.8 \\
\hline & Accept reluctantly & 1.8 & 2.6 & 2.1 \\
\hline & Refuse & 0.0 & 7.9 & 3.2 \\
\hline & Total & 100.0 & 100.0 & 100.0 \\
& Accept happily & $7=57)$ & $(N=38)$ & $(N=95)$ \\
\hline $35-44$ & Accept with no special feeling & 22.9 & 69.8 & 72.4 \\
\hline & Accept reluctantly & 2.7 & 26.4 & 24.4 \\
\hline & Refuse & 0.0 & 1.9 & 2.4 \\
\hline & Total & 100.0 & 1.9 & 0.8 \\
\hline & Accept happily & $(N=74)$ & $(N=53)$ & $(N=127)$ \\
\hline $45+$ & Accept with no special feeling & 69.0 & 60.0 & 65.9 \\
\hline & Accept reluctantly & 25.9 & 20.0 & 23.9 \\
\hline & Refuse & 3.4 & 10.0 & 5.7 \\
\hline & Total & $\mathbf{1 . 7}$ & $\mathbf{1 0 . 0}$ & 4.5 \\
\hline & & $\mathbf{1 0 0 . 0}$ & $\mathbf{1 0 0 . 0}$ & 100.0 \\
& & & $(\mathbf{N = 3 0 )}$ & $(N=88)$ \\
\hline
\end{tabular}

Source: Author's survey [done]

Notably, as shown in Table 2, there is a significant difference between the attitudes towards political promotion of males and females by age group. The proportions of women younger than 35 and older than 44 choosing to 'accept reluctantly' and 'refuse' a political promotion are considerably higher than those for women aged $35-44$, as well as those of men of the same age groups. A possible reason for this is that in their younger years, women are expected to devote more time to family responsibilities, including getting married and having children. When they 
get older, at 45 years of age and above, they may be less interested in such an opportunity because they feel less competitive than their male counterparts due to the retirement age policy. Abundant evidence can be found in the qualitative data, and some of this is discussed below.

As revealed in the in-depth interviews, men show much more eagerness than women in accepting a promotion opportunity, and their motivations differ from those of their female counterparts. Below are some examples:

“- Imagine you were offered a higher level position in your political career, how would you accept it?

- Who doesn't want such an opportunity? The issue is whether it comes to you or not.

- What about the greater responsibilities and requirements attached with the new position? Have you ever thought that you could not handle them?

- Oh, I never mind that situation... 'Anyone would know how to raise the flag when it's his turn to keep it' [Cờ đến tay ai thì người ấy phất]. I believe that I could do the work well. (Male, aged 40, single, Head of department, district level, North)

"Sure. Political promotion is my highest target. Being a man, you'll put your political career on top of all. If you succeed then people will admire you... I really want to be that way". (Male, aged 38, married, 2 children, DeputyHead of department, district level, South) "If I say "no" it could be somewhat dishonest... To be honest, people often said "in this world, the best trade to be in is the King's trade" [Ơ trên đời, chỉ có buôn Vua là lãi nhất]. I bet that you understand what I mean". (Male, aged 52, married, 2 children, Head of department, commune level, North).

Even when men say 'no' to a promotion opportunity, or are less interested in it, that is mainly because of their feeling of hopelessness in approaching the opportunity, due to their old age and/or limited leadership competence. The following avowal of a man aged 50 is a striking example:

"I won't... Actually, it is like an unreal condition for me. At my age, all those political ambitions are not suitable any more. I know what I can do and hope at this stage". (Male, aged 50, married, 1 child, Deputy-Head of department, commune level, South)

On the other side, women, while saying that they would accept the political promotion, demonstrated their concern about the responsibilities attached to the new position and considered their ability to fulfil both family and work requirements. Indeed, many women felt worried rather than happy about receiving a political promotion. Some articulated the difficulties associated with their double burden when promoted, others expressed their own limitations in working skills that may hinder the proper fulfilment of the new responsibilities. Their concerns also reflected a lack of confidence among women, which might significantly hinder their political ambition. Vianello et al. (1990, p.8) also suggested in the introduction to a comparative study of gender discrimination: "Many factors are necessary to allow women access to power, but one prerequisite is that women think that it is proper for them to participate in public life to the same extent as men think that it is". However, whether this results from either their lower level of working competence or lower self-confidence compared to men, this needs to be further investigated. Below are some examples of women's responses to the opportunity of being promoted:

"That sounds good, but my decision would depend on certain conditions. I'd only accept it if I feel that the new position is close to my strength and professional abilities. Otherwise, I would rather refuse. I'm afraid of being a grain of wheat in a bushel of chaff'. (Female, aged 37, married, 2 children, Head of department, commune level, North) 
"Yes, I do. But, as a matter of fact, there are many things to be considered. To be promoted, to whatever level, we must make a tremendous endeavour at work and at home; for career, for family and children. It's not that easy... Even I, at this age and in this position, sometimes still feel frustrated". (Female, aged 43, married, 2 children, Deputy-Head of department, district level, North)

"If I'm trusted by my superiors, I'll try. In my point of view, to be promoted means you are recognized and respected at a higher level in terms of profession and charisma. This is something you can be proud of, but it's also perturbing. There are so many issues accompanying the higher position. In addition, I'm concerned very much about my family, about how to keep it as stable as previously. I don't dare to say for sure that I can keep my career independently from family concerns". (Female, aged 42, married, 2 children, Head of department, commune level, Central)

For certain women who would refuse an opportunity to be promoted, their reasons are strongly attached to family duties and fear of their marriage relationship breaking down. Here are some cases in point:

"At this point I have only one daughter. It's a bit too late to have the second child, isn't it? My husband and I expect to have a son next year. When I come back (from the Academy), I should wait... maybe after several years... assuming that I still have a similar opportunity. I need to focus on family duty first. I'm afraid that I would lose my happiness if I go ahead with the promotion at this time, ignoring my husband's desire". (Female, aged 39, married, 1 child, Head of department, provincial level, Central)

"Ultimately, people pursue happiness. If family is overlooked, it will risk being broken. Then what is the meaning of your endeavour? Indeed, I don't have many political opportunities, and I don't desire it much". (Female, aged 31, married, 1 child, South).
"Political ambition is something secondary to me. Rather, I care very much about attaining a good professional job and a happy family life. I can't imagine what happens if my family is not happy while I pursue my political career..." (Female, aged 45, married, 2 children, North)

"If I do not make family life my first priority, my husband would feel unhappy, and he might turn to other girls who are younger and more beautiful than me". (Female, aged 43, married, 2 children, North).

A list of key reasons were used in the survey in order to deepen the understanding of the respondents' grounds for accepting or not accepting a political promotion opportunity. The analysis shows interesting differences among men and women, and among different age groups. Figure 1 presents several key reasons for respondents' happy acceptance of an offer of political promotion, by sex. More than one half of male respondents would accept the offer since they believe it would help achieve their professional goals. This proportion is almost 9 percentage points higher than that for females. A possible implication is that men are more likely than women to expect good outcomes in terms of professional reputation from climbing higher on the political ladder. Supporting evidence of this inference can also be found in the following section of this chapter, showing respondents' perceptions of the reciprocal impacts of political career, profession, and family life.

Interestingly, regarding the reason for challenges and opportunities to show personal leadership talent, the proportion of female respondents in agreement is higher than that for males. For these groups by gender, the respective proportions are highest in absolute terms; almost 85\% for females and nearly $74 \%$ for males. Higher agreement among females may reflect the fact that these respondents feel disadvantaged in accessing political opportunities, while they believe they can do the job just as well as their male counterparts. From another perspective, 
there is almost no difference between responses from males and from females to the idea that if they accept an offer of political promotion they could encourage others to demonstrate their competence as well $(49.3 \%$ vs. $50 \%$, respectively).

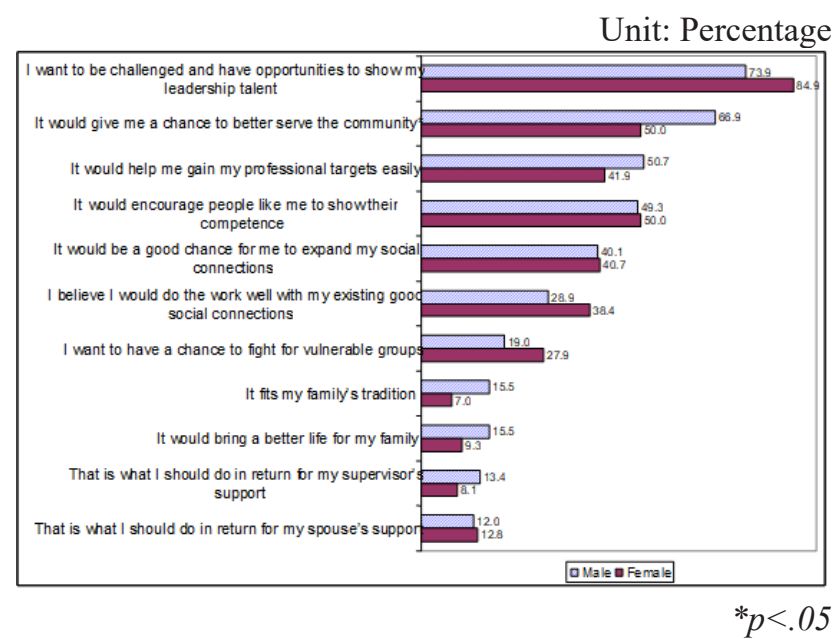

Figure 1: Reasons for the happy acceptance of an offer of political promotion, by gender.

Source: Author's Survey

Family tradition is a reason rarely given for respondents' happy acceptance of offers of political promotion. The proportions of male and female respondents citing this reason are only just over $15 \%$ and nearly $7 \%$, respectively. Recalling the fact that the male respondents have, on average, slightly more relatives that currently and have previously worked as leaders compared to their female counterparts (3.34 vs. 3.11 relatives), these figures still indicate that men are expected to succeed in a political career to a higher extent than women.

Similarly, spouse support, supervisor support, and a better life for the family fail to emerge as likely reasons for a respondent's happy acceptance of an offer of political promotion, whether the respondent is male or female. Moreover, the small differences between men's and women's statements about the impacts of supervisor support and the impacts of expectations of having a better family life may be a sign of men's privilege at work, but may also reflect the pressures on men in their bread winner roles.
Also shown in Figure 1, nearly $29 \%$ of male respondents believe they would work well in a higher position with their existing social connections. This figure is higher among their female counterparts, by almost 10 percentage points. To a certain extent, this reflects women's greater confidence in getting the job done with their good social connections. Interestingly, to both male and female respondents, this reason is of less importance than the purpose of increasing social connections itself. For respondents happily accepting an offer of political promotion, the proportions of those citing the reason of 'expanding social connections' are $40.1 \%$ and $40.7 \%$ for males and females, respectively. That is, while political promotions appear to rely on good social connections, it is their induced effect on expanding a social network that attracts respondents.

Over two thirds of male respondents would accept the offer as it would give them the chance to serve the community better. This figure is dramatically higher than that among females $(50 \%)$. This difference is statistically significant at $p<.05$. From another aspect, while only $19 \%$ of male respondents would accept offers because it would give them the chance to serve vulnerable groups, nearly $28 \%$ of their female counterparts would do so for the same reason. A possible explanation here is that female politicians may think of their targeted community in a more concrete way than males. In addition, women themselves traditionally belong to vulnerable groups. Therefore, they are more likely than men to think that they should fight for these groups' benefit.

In sum, the reasons that are more important among male respondents include: easier attainment of professional targets; family tradition; return for supervisor support; better life for the family; and a chance to better serve the community. Other reasons, meanwhile, are deemed by female respondents as more motivating for their happy acceptance of an offer of promotion. The difference in men's and women's concerns about 
demonstrating personal leadership competence and fighting for vulnerable groups may also reflect women's greater potential for solving social inequalities once they are empowered. This is an important implication for women's empowerment, and needs to be studied further.

The reasons why several respondents opted to either reluctantly accept or refuse offers of political promotion are also important in understanding the difference in the grounds for behavior among various groups. As presented in Table 3, the most notable difference between males' and females' answers lies in the time required for family. Only one third of males who would reluctantly accept or refuse an offer of political promotion explain that they need to spend more time with their families, while the same reason is cited by nearly $77 \%$ of females. Obviously, family burden is always one of the biggest issues facing women regarding political promotion opportunities.

Similar patterns of answers by gender are exhibited with respect to the reasons given for requiring more time for attaining professional targets, and the lack of talent to do the job well in higher positions. Such reasons are indicated by one third of relevant male respondents and by over $38 \%$ of females. These results suggest that women are less confident than men in their leadership abilities when in higher positions and also demonstrates their preference for a more stable way to a secure life: having good professional achievements.

Table 3: Reasons for reluctant acceptance or refusal of an offer of political promotion, by gender

\begin{tabular}{l|c|c|c|c}
\hline & $\begin{array}{c}\text { Male } \\
(\%)\end{array}$ & $\begin{array}{c}\text { Female } \\
(\%)\end{array}$ & Overall (\%) & $\begin{array}{c}\text { Pearson Chi- } \\
\text { Square } \\
\text { Sig. (2-sided) }\end{array}$ \\
\hline $\begin{array}{l}\text { Iwant to spend more time on my professional } \\
\text { targets }\end{array}$ & 33.3 & 38.5 & 36.8 & .829 \\
\hline I want to spend more time with my family & 33.3 & 76.9 & 63.2 & .067 \\
\hline $\begin{array}{l}\text { I do not have the talent to work well at } \\
\text { higher positions }\end{array}$ & 33.3 & 38.5 & 36.8 & .829 \\
\hline $\begin{array}{l}\text { I'm afraid of having more obligations and } \\
\text { responsibilities }\end{array}$ & 16.7 & 7.7 & 10.5 & .554 \\
\hline My supervisor would not support me & 16.7 & 0.0 & 5.3 & .130 \\
\hline My spouse would not support me & 0.0 & 7.7 & 5.3 & .485 \\
\hline $\begin{array}{l}\text { I would not do the work well without good } \\
\text { social connections }\end{array}$ & 16.7 & 7.7 & 10.5 & .554 \\
\hline $\begin{array}{l}\text { Such a decision is considered too ambitious } \\
\text { for a person like me }\end{array}$ & 0.0 & 7.7 & 5.3 & .485 \\
\hline
\end{tabular}

Source: Author's survey

More obligations and responsibilities at work, and no effective work fulfilment without good social connections are of similar importance by gender. These reasons account for nearly $17 \%$ of male respondents and about $8 \%$ of females who would accept reluctantly, or refuse, an offer of political promotion. These findings are consistent with the suggestion of Epstein (1990), that men are more likely than women to turn down promotions because of the concern that they cannot handle new responsibilities. However, this tendency is weak, with small absolute proportions. In qualitative terms, very few men in this research mentioned these impediments during interviews. Instead, as presented previously in this section, most show eagerness to go ahead with the promotion, and strongly believed in their own leadership abilities.

Conversely, reasons such as a lack of spouse support and the fear of being considered too ambitious are deemed as 'important' by no male 
respondent and by nearly $8 \%$ of relevant females. Meanwhile, the lack of a supervisor's support is given as an explanation by one sixth of male respondents, and by no females, for refusing or accepting an offer of political promotion with reluctance. This suggests, although imperceptibly, that women are facing gender prejudice in pursuing political achievements. In fact, the value and belief systems favouring men in political leadership are supported significantly by the traditional expectations of family and society. Therefore, under the constant pressure of reconciling role conflicts, many female political candidates refuse to run for higher leadership positions, although they are encouraged and supported strongly by colleagues. The following example illustrates this argument:

Mrs. T is a talented deputy head of a province's Education and Training Department, whose husband works as a vice president of the province's People's Committee. Prior to the $17^{\text {th }}$ Communist Party Congress of that province, both she and her husband were nominated for the election to the Party's committee of executive members (49 members). Despite the insistence of others before the commencement of the Congress, she refused the proposal with the explanation "Having my husband in the Committee is enough". Unfortunately, her husband failed in the election. After the Congress, some people told her "If only you hadn't withdrawn, at least one of member of your family would have a seat in the Committee". She bitterly replied: "No, you're completely wrong. It was too lucky that I withdrew. Can you imagine that I succeed where my husband failed? How can I survive under my in-laws' pressure?" Source: Author's field notes

The analysis of the responses by age also reveals some interesting information (Table 4). For most respondents who would reluctantly accept or refuse offers of political promotion, giving time to their families is an important reason. This reason is also given by $80 \%, 75 \%$, and over $55 \%$ of relevant respondents in the age groups 24-34, 35-44, and of 45 and over, respectively. Respondents less than 45 years' old contribute the biggest proportion among those who give this reason. This represents the perception that building up family life is one of their highest priorities at this period of their lives. However, when getting older, they would be less concerned as shown by the negative correlation of time spent for family and respondents' age. After reaching the age of 45, respondents feel less burdened with spending time with family, and therefore more time could be allocated to their career.

At the age of 35-44, those who reluctantly accept or refuse offers of political promotion are more likely to explain their decision by citing the time needed for professionalachievements. Dedicating more time to attaining professional targets acquires a relatively high level of importance $(75 \%)$ among the relevant respondents in this age group, whilst failing to account for the large share of respondents in other age groups $(20 \%$ and over $33 \%$ for respondents in the age groups 24-34 and 45 and over).

A concern about having no talent to work well at higher positions is the reason given by $20 \%$ and nearly $56 \%$ of relevant respondents in the age groups 24-34 and of 45 and over, respectively. However, this reason fails to explain, to any extent, the reluctant to accept or refuse an offer of political promotion by respondents between $35-44$. Together with the fact that $20 \%$ of the young respondents between 24-34 feel a lack of supervisor support, this finding should draw policy makers' attention. For young political elites who possess relatively less experience, supervisor support would be a key ingredient for political success. Mentoring and leadership training activities prior to and during the early stage of a political career may be useful to counter this obstacle. 
Table 4: Reasons for reluctant acceptance or refusal of an offer of political promotion, by age Unit: Percentage

\begin{tabular}{|c|c|c|c|}
\hline & 24-34 & $35-44$ & $45+$ \\
\hline I want to spend more time on my professional targets & 20.0 & 75.0 & 33.3 \\
\hline I want to spend more time with my family & 80.0 & 75.0 & 55.6 \\
\hline I do not have the talent to work well at higher positions & 20.0 & 0.0 & 55.6 \\
\hline $\begin{array}{l}\text { I'm afraid of having more obligations and responsibilities } \\
\text { in my work }\end{array}$ & 0.0 & 0.0 & 22.2 \\
\hline My supervisor would not support me & 20.0 & 0.0 & 0.0 \\
\hline My spouse would not support me & 0.0 & 0.0 & 11.1 \\
\hline $\begin{array}{l}\text { I would not do the work well without good social } \\
\text { connections }\end{array}$ & 0.0 & 0.0 & 22.2 \\
\hline $\begin{array}{l}\text { Such a decision is considered too ambitious for a person } \\
\text { like me }\end{array}$ & 11.1 & 11.1 & 11.1 \\
\hline
\end{tabular}

Source: Author's survey

Reasons such as more obligations and responsibilities at work, lack of spouse support, and no effective work fulfilment without good social connections are only relevant to respondents of at least 45 years old who would accept reluctantly, or refuse, an offer of political promotion. Even so, the relevance of these reasons is not high in absolute terms, as indicated in Table 4.

Notably, there was no difference by age group when relevant respondents were asked whether accepting a political promotion would be too ambitious. The proportion of those indicating this reason is over $11 \%$ for each of the three age groups. As stated, no men in the survey answered that they were under such pressure. Thus it can be inferred that, to some extent, this pressure applies evenly for women in all age groups.

\section{DISCUSSION}

Evidently, there are different tendencies in the political behaviors of Vietnamese men and women, as shown in their attitudes towards promotion opportunities. Although being political elites, women face more difficulties than men in their political careers.

Generally, cultural norms are the most popular reason leading to the limitation of women's political careers. As similar to the situation in many other countries previously, Vietnamese traditional cultural norms take for granted that men's political ambition is compatible with a man's responsibility, while it is less easy for women to have such ambitions. Therefore, unlike women, men are not hindered in their careers by having a stable family life, because the higher they are on the career ladder, the greater resources they can muster to support their family. This, as Barnett et al. (1995) argued, can create different expectations about work and home obligations for men and women, even though they are similar in the labour market. Women often experience more distress than men in relation to work/home role conflict and tend to feel more tired and emotionally drained than men, due to the time and energy spent on competing responsibilities at work. Similar statements have been made by several authors when studying gender issues in other communities in the 1980s and 1990s (Chusmir, 1986; Kramer and Melchior, 1990; Zappert and Weinstein, 1985). As a result, women's level of gender role conflict is higher than that of men, and women in top positions often encounter more difficulties in family life than their male colleagues.

Research results also imply that men can be affected negatively by work/home role conflict, due to the traditional belief that men's central 
role is in paid work rather than at home. Indeed, not every man is completely happy political promotion opportunities. In fact, with the expectations and social pressures that men feel, they will most likely have to adopt an acceptance and commit themselves to the political path. Otherwise, they may feel guilty for not fulfilling their responsibility. This is compatible with the argument of Windle and Dumenci (1997, p.626) : "occupational role functioning would be more salient than parental or family role functioning to mental health for men, whereas parental or family role functioning would be more salient than occupational role functioning to mental health for women". However, this issue needs to be studied further.

Returning to the case of women, barriers to Vietnamese women in political leadership are not only a result of traditional cultural norms, but also rooted in certain policies that were originally created to protect women. As shown in the research results, gender differences in attitudes towards political promotion become clearer when analysed through the perceptions of different age groups. One can quite easily understand the main reason behind men and women's choices - the policy on retirement age as set by the Labour Code and the Law on Social Insurance.

In the formal sector, women in Vietnam are required to retire five years earlier than men - at the age of 55 years as compared with 60 years for men. This policy was introduced in recognition of women's contribution to work and family life where early retirement is seen as a reward. However, in practice it has some negative impacts for working women. It is clear that earlier retirement significantly prevents women from being promoted to top leadership and senior positions since they will be forced to retire before they are able to reach those positions (Rama, 2001; World Bank et al., 2006).

Accordingly, the time for women to receive offers of promotion is 5 years shorter than for men. In 2003, Decision 27/2003/QD-TTg (Vietnamese Government, 2003) stated that at the time of a first appointment, official and public employees must not be over 55 for men or 50 for women, except for the posts of deputy-head and head of sections in urban and rural districts or equivalent posts. (For these posts, the age for first time appointments must not exceed 45 years old for both men and women). The purpose of this policy is to ensure that the incumbent will have at least 5 years (one office term) working in the position. However, the policy in fact considerably deters women's political ambition (World Bank et al., 2006). Only in 2006 did Article 11 of the Law on Gender Equality stipulate that: 'Man and woman are equal in terms of professional qualifications and age when they are promoted or appointed to the same posts of management and leadership in agencies and organizations' (National Assembly of the Socialist Republic of Vietnam, 2006:4). However, the influence of the Law on Gender Equality is modest and its stipulations to date are mainly suggestive rather than compulsory.

In summary, being a leader is never seen as a proper substitute for being a 'good woman' in the case of Vietnamese political elites. In other words, choosing work over family is not widely accepted for women. Unlike women in other countries, Vietnamese women do not easily solve the problem of role conflicts by having a more flexible occupations in terms of less compulsory overtime and adjusting working hours to women's needs, as suggested by authors previously (Bergman, 1992; Charles, 1992; Fiorentine, 1988; Fowlkes, 1987; Jacobs, 1989; Kaufman, 1992; Moore, 1992). Together with the hindrances caused by cultural norms, the Government's inappropriate policy on retirement age creates significant barriers to women's political ambitions. They are therefore not as eager as their male counterparts to attain political promotion. 


\section{CONCLUSION}

With research evidence, it can be said that the majority of Vietnamese political elites are willing to take up opportunities to be promoted in their careers. However, the level of eagerness has certain differences between men and women. In general, women's readiness to accept opportunities is often lower than that of men. The research results, both qualitative and quantitative, show that the causes of women's hesitation or even refusal of political advancement opportunities are largely due to social expectations on their traditional gender roles. In addition, some improper legal frameworks and policies significantly contribute to women having less political ambition and giving up such ambition earlier than their male counterparts.

With the persistence of traditional values and cultural norms in Vietnam, coupled with the continuing application of policies that are no longer appropriate to actual conditions, such as retirement policies, many difficulties and challenges exist on the road to women's political advancement in Vietnam. Significant changes in both thought and action should be made in order to make considerable progress in this area, contributing to the realization of gender equality as one of the Millennium Development Goals that Vietnam has committed to and is striving to achieve.

\section{LIMITATION AND STUDY FORWARD}

This article attempts to understand the profound reasons why Vietnamese women are often inferior to men in their political careers. However, the conclusions drawn from this study are relatively limited, due to the small size of the research sample. The number of respondents who refused or reluctantly accepted their opportunity for promotion in the research sample was also very small. Therefore, although the findings from this study are quite interesting, the conviction of quantitative data will be better with a larger sample size. In further studies on this topic, the authors will try to overcome this limitation and use appropriate statistical tests to better convince readers about the reliability of quantitative data.

With regard to the research idea, suggestions for further studies include the investigation of other features and components of Vietnamese political culture towards the gender issue, for example risk aversion among political leader regarding their decisions to appoint a female or male leader. The personal background of Vietnamese political elites is also an interesting area for gaining a comprehensive understanding of this group of gatekeepers.

\section{ACKNOWLEDGEMENT}

The authors would like to express our gratitude to our colleagues at the Ho Chi Minh National Academy of Politics for providing us with support in doing the research. Their comments on research contents and methods are very valuable to us, not just in this study. We are also grateful to all the informants who agreed to participate in our survey and interviews anonymously as without them, this research would not have been completed. Their extensive assistance during our fieldwork has been one of the most important factors in the completion of this research.

\section{AUTHORS CONTRIBUTION}

Tran Thi Huong and Le Thi Thuc co-conducted this research, in which the two authors discussed the content, methodology, and conducted the field research. Le Thi Thuc designed the survey plan and performed quantitative statistical analysis, then developed the draft manuscript with input from both authors. Tran Thi Huong is responsible for analyzing qualitative data and participated in finalizing the manuscript. Both authors read and approved the final manuscript. 


\section{REFERENCES}

1. Barnett, R.C.and G.K. Baruch. (1985). Women's Involvement in Multiple Roles and Psychological Distress. Journal of Personality and Social Psychology 49(1), 135-145.

2. Barnett, R.C., S.W. Raudenbush, R.T. Brennan, J.H. Pleck, and N.L. Marshall. (1995). Change in Job and Marital Experiences and Change in Psychological Distress: A Longitudinal Study of DualEarner Couples. Journal of Personality and Social Psychology, 69, 839-850.

3. Bergman, B. (1992). "The Job of Housewife" in Feminist Philosophies: problems, theories, and applications. edited by J.P. Sterba, J.A. Kourany, and R. Tong. Englewood Cliffs: N.J.: PrenticeHall.

4. Charles, M. (1992). Cross-national Variations in Occupational Sex Segregation. American Sociological Review 57(4):483-502.

5. Chusmir, L.H. (1986). Gender Differences in Variables Affecting Job Commitment among Working Men and Women. Journal of Social Psychology 126:87-94.

6. Epstein, C.F. (1990). Foreword. In Gender Inequality: A Comparative Study of Discrimination and Participation. London, Newbury Park, Calif: Sage Publications. 19-22.

7. Etzioni-Halevy, E. (2004). Foreword. Current Sociology 52(3):311-316.

8. Fiorentine, R. (1988). Increasing Similarity in the Values and Life Plans of Male and Female College Students? Evidence and Implications. Sex Roles 18:143-158.

9. Fleschenberg, A. (2003). Paradoxes and Anomalies: Female Political Participation and Engendered Development. University of Duisburg-Essen and University of Erlangen-Nurnberg.

10. Fowlkes, M.R. (1987). Role Combinations and Role Conflict: Introductory Perspective." in Spouse, Parent, Worker, edited by F.J. Crosby. New Haven, CT: Yale University Press.

11. Gray, J.D. (1983). The Married Professional Woman: An Examination of Her Role Conflicts and Coping Strategies. Psychology of Women Quarterly 7:235-243.

12. Inter-Parliamentary Union. (2000). Politics: Women's Insight. Geneva, New York: InterParliamentary Union.

13. Jacobs, J. (1989). Revolving Doors: Sex Segregation and Women's Careers. Stanford, CA: Stanford University Press.

14. Kaufman, D.R. (1992). Professional Women: How Real Are the Recent Gains? in Feminist philosophies, edited by J.A. Kouraney, J.P. Sterba, and R. Tong. Englewood Cliffs, NJ: PrenticeHall.

15. Kent, R.L.and S.E. Moss. (1994). Effects of Sex and Gender Role on Leader Emergence. Academy of Management Journal 37(5):1335-1346.

16. Kenworthy, L.and M. Malami. (1999). Gender Inequality in Political Representation: A Worldwide Comparative Analysis. Social Forces 78(1):235-268.

17. Kramer, D.A.and J. Melchior. (1990).Gender, Role Conflict, and The Development of Relativistic and Dialectic Thinking. Sex Roles 25:553-573.

18. Moore, D. (1992). Labor Market Segmentation and Its Implications: Social Justice, Relative Deprivation and Entitlement. New York: Garland Publishing.

19. National Assembly of the Socialist Republic of Vietnam. (2006). Law on Gender Equality. National Assembly of the Socialist Republic of Vietnam, 10th Session of the XI Legislature.

20. Nelson, B.J.and N. Chowdhury. (1994). Women and Politics Worldwide. New Haven: Yale University Press.

21. Norris, P.and R. Inglehart. (2001). Cultural Obstacles To Equal Representation. Journal of Democracy 12(3):126-140.

22. Rama, M. (2001). The Gender Implications of Public Sector Downsizing: The Reform Program of Vietnam. in Policy Research on Gender and Development, Working Paper Series No. 19. Washington, DC: World Bank.

23. United Nations. (2000). The World's Women 2000: Trends and Statistics. New York: United Nations.

24. Vianello, M., R. Siemienska, N. Damian, E. Lupri, R. Coppi, E. D’Arcangelo, S. Bolasco, and C.F. Epstein. (1990). Gender Inequality: A Comparative Study of Discrimination and Participation. London, Newbury Park, Calif: Sage Publications.

25. Vietnamese Government. (2003). Promulgating the Regulation on Appointment, Reappointment, Shift, Resignation and Removal from Office of Leading Officials and Public Employees. The 
National Legal Database. URL: http://vbqppl.moj.gov.vn/law/en/2001 to_2010/2003/200302/20 0302190006 en.

26. Wajcman, J. (1998). Managing Like A Man: Women and Men in Corporate Management. University Park, PA: Pennsylvania State University Press.

27. Weitzman, L.J. (1984). Sex Role Socialization: A Focus on Women. in Women: A Feminist Perspective, edited by J. Freeman. Palo Alto, CA: Mayfield.

28. Windle, M.and L. Dumenci. (1997). Parental And Occupational Stress As Predictors Of Depressive Symptoms Among Dual-Income Couples: A Multilevel Modeling Approach. Journal of Marriage and the Family 59:625-634.

29. World Bank. (2001). Summary: Engendering Development Through Gender Equality in Rights, Resources, and Voice: World Bank and Oxford University Press.

30. World Bank, ADB, DFID, and CIDA. (2006). Vietnam Country Gender Assessment. Hanoi: URL: 